\title{
GUIDE AGAINST ELDERLY ABUSE AMONG THE EFIK PEOPLE OF SOUTH-SOUTH, NIGERIA: AN EXAMINATION OF EXODUS 20:12
}

\author{
Akpanika, Ekpenyong Nyong \\ Department of Religious and Cultural Studies, University of Calabar, Nigeria \\ E-mail: en.akpanika@unical.edu.ng
}

\begin{abstract}
Elderly abuse is an issue that has not been given much attention particularly among the Efik speaking people of South-South, Nigeria. The unjust and abusive treatment given generally to the elderly is gradually on the increase in the 21 st century. The growing number of parents experiencing abuse, violence and insult in contemporary Efik society by caregivers or sometimes their children desire some attention. Today, since most elderly persons are not seen as breadwinners of the family, they are regarded as not being important and as such, not given the same respect as they deserve. This paper examines the biblical injunction of Exodus 20:12 to honour one's father and mother and its implication among the Efik People of South-South, Nigeria. God through Moses gave the children of Israel some moral laws that guided their relationship with the aged and elderly. The commandment in Exodus 20:12 to honour one's father and mother were primarily to protect them from abuse and neglect. Similarly, among the Efik people, some moral laws protected the aged and the elderly from possible abuse. This obligatory respect for the aged which was a panacea for family stability in the patriarchal period and Efik traditional setting is gradually losing its relevance in contemporary times. This cultural shift calls for reinvigoration in an attempt to stop elderly abuse among the Efik people. The paper adopted the qualitative research method using the hermeneutical and historical approach and discovered that globalization, urbanization and poverty have contributed in no small measure to the devaluing respect that the Efik people had for the aged and recommends the introduction of gerontology as part of civic education in Primary and Secondary schools to recapture these values.
\end{abstract}

Keywords: Aged, Efik, Hermeneutics, Elderly, Globalization and Urbanization.

\section{INTRODUCTION}

Every human society has a culture and it is this culture that regulates the behaviour of the people. It sets out the values, the taboos and the standard of behaviour that is expected of every individual or group in that society. For Efik people of South-South Nigeria, one of such values include the value placed on elders. The concept of elderships was not defined by wealth or fame but by character and integrity. Long-life was attributed to uprightness and good character. The traditional social welfare system had an inbuilt domestic mechanism that could care for both the strong and the weak in the family. Where individuals were poor and unable to meet their necessities, the extended family provided for their members to avoid bad name within the community. In some cases, some kind of community resources also existed, to satisfy the needs of the poor and needy. Those without land were allocated community land for subsistence cultivation of agricultural products and in return pay tribute to the Chief. This was done because the protection of the family name was better than silver and gold. Besides, the practice of individuals marrying many wives among the Efik people was not just for labour force but security and care at old age. This form of traditional values, prevented insult and abuse against the elderly since they were seen as models in the traditional setting.

The 21 st-century culture is adrift from this traditional value. Ageism is very much part of society. The elderly are discriminated against, at home and in society. They are 
stigmatized, marginalized and accused. They are believed to be of no use to the family and the society once they are retirement. This is so because, according to Pritchard, "they are not seen as producing anything for the society in which they live; they are considered to have had their life so why border others" (Pritchard 1992 p. 16). Today, youths are glorified and old age is despised. As future leaders of tomorrow, the high profile accorded to the youths has led to the devaluation of the elderly ones in many different ways both at work and society. Pritchard argues that the reason for the disrespect is because "elderly persons are believed to be of no use once they are retired and because they produce nothing for the society in which they live ... they are not important" (16). Being young has its advantages, so does being old. In God's design, there is something special about each phase of life. Youths have enormous energy and enthusiasm, while older people have great experience and wisdom. Proverb 20: 29 points out that "The glory of young men are their strength, grey hair the splendour of the old". Although every age group has its associative benefits and challenges, they vary amongst people, cultures and traditions. For instance, a particular community might view their older people with great honour in contrast with another that may see them as a burden. The objective of this paper is to examine the reasons for the increasing number of abuse, insult and neglect of the aged in contemporary time, despite the seriousness attached to it both in the Bible and the Efik traditional setting and see how these values could be reinvigorated in contemporary Efik society through civic education.

\section{The Biblical Concept Of Ageing And Respect In Old And New Testaments}

From a biblical perspective, human beings created in the image and likeness of God were expected to experience immortality just like God until sin entered the world through Adam and Eve (Duke 2018). Even then, the first generation of human beings lived for centuries before ageing or dying. For instance, the Bible records that Adam lived for Nine Hundred and Thirty (930) years (Genesis 5:5) before he died. Noah lived Nine Hundred and Fifty (950) years (Genesis 9:29), Methuselah lived Nine Hundred and Sixty Nine (969) years (Genesis 5:27), Seth lived Nine Hundred and Twelve (912) years (Genesis 5:8), Canaan lived Nine Hundred and Ten (910) years (Genesis 5:) Enosh lived Nine Hundred and Five (905) years (Genesis 5:11), Lamech lived Seven Hundred and Seventy-Seven (777) years (Genesis 5:31), Shem lived 500 years (Genesis 11:11) and Arpachshad Noah's grandson lived Four Hundred and Thirty-Eight (438) years.

But from the generation of Abraham to the generation of Noah, life expectancy progressively declined to between 180 to 120 . For instance, Abraham lived 175 years (Gen. 25:7), Isaac lived 180 years (Gen. 35: 28). In Genesis 6:3 before Noah's flood, God stated that the maximum lifespan of man shall be 120 years and in Psalm 90:10 life expectancy was further reduced to 70 or 80 years during the time of David. "The length of our days is seventy years or eighty if we have strength..." (Ps. 90:10). However, it important to note that from the biblical perspectives, God places great importance on the aged, ensuring that appropriate care is given to the elderly. Bible passages both in Old and New Testaments are replicated with promises for those who honour and respect the aged and the elderly.

Dishonour to parents and the aged was therefore seen as a serious moral violation before God and man both in the Old and New Testaments. Their frailty was not to be taken for granted. In Israel, elders were customarily held in high esteem and respected for their wisdom, knowledge, experience and sound judgment. This respectful attitude to elders was reflected in Job 32: 6-7 when Elihu said to Job: "I am young in years and you are very old, 
therefore, I was afraid and dared not declare my opinion to you. I said, age should speak and the multitude of years should teach wisdom".

God through Moses gave the children of Israel some moral laws that were to guide their relationship with the aged and elderly. As a commandment, He instructed them to "respect their father and mother, so that they may live long in the land"(Exo. 20:12). In Leviticus 19:32 God again commanded the younger ones to rise before the grey-headed and honour the presence of an old man, for the fear of God. The reason for this obligatory honour and respect was because grey hair was a crown of splendour, it was attained by a righteous life. Long life is the reward of the righteous; grey hair is a glorious crown (Prov. 16: 31).

By implication disrespect to the aged meant disrespect to God and the law of God. This is properly captured in Prov. 23:22-25 when the writer declared: Listen to your father, who gave you life and do not despise your mother when she is old. Buy the truth and do not sell it; get wisdom, discipline and understanding. The father of a righteous man has great joy; he who has a wise son delights in him. May your father and mother be glad, may she who gave you birth rejoice" (Prov. 23: 22-25). Even grandchildren were seen as the crowning glory of the aged; parents were the pride of their children (Prov. 17:6). The righteous will flourish like a palm tree, they will grow like a cedar of Lebanon; planted in the house of the Lord, they will flourish in the courts of our God. They will still bear fruit in old age, they will stay fresh and green, proclaiming, The Lord is upright; He is my Rock and there is no wickedness in Him (Ps. 92:12-15). Job declared: "I am young in years and you are very old, therefore, I was afraid and dared not declare my opinion to you. I said, age should speak and the multitude of years should teach wisdom (Job 32: 6-7).

Therefore, those who dishonour, disrespect and insult the aged in one way or the other were condemned and God commanded the death penalty for such rebellious children: If a man has a stubborn and rebellious son who does not obey his father and mother and will not listen to them when they discipline him, his father and mother shall take hold of him and bring him to the elders at the gate of his town. They shall say to the elders, this son of ours is stubborn and rebellious. He will not obey us. He is a profligate and a drunkard. Then all the men of his town shall stone him to death. You must purge the evil from among you. All Israel will hear of it and be afraid (Deut. 21:18-21 NIV).

\section{Exegesis Of Exodus 20:12}

The Ten Commandments generally referred to as Decalogue found in Exodus 20:317 and in Deuteronomy 5: 7-21 contains some moral laws which guided the children of Israel in their relationship between man to God and man to man. The first commandment spells out man's responsibility to God; the obligation of man to God (Exodus 20: 3-11). Following the structure of the Ancient Near East, God, first of all, identified himself to His subjects and elevates Himself as the only object of worship and strictly forbidding the worship of any other creatures (v3). The second commandment (v 4) refers to the type of worship to be rendered and forbids a man from making any image or picture of any form as an object of worship. The third and the fourth commandments are concerned with the manner of worship, which must be done with all possible reverence and seriousness. False oaths and using the name of the Lord indiscriminately or in vain are forbidden (7-8).

The fifth commandment marks a division between the laws that deal with man's relation with God and those that relate to his fellow man. The emphasis in the second division of the tablet deals with man's relationship with the man beginning with children's 
responsibility to their parents. These laws deal with the duties and responsibilities we owe to our neighbours and relations but of particular interest is the law that enjoins us to honour our father and our mother. Matthew Henry outlines three specific duties that were obligatory of children to their parents from this passage. He opines that children obligated to give respect, obedience and submission to their parents. To further elaborate this, he pointed out that:

1. Respect for parents implies decent respect to their persons, an inward esteem of them outwardly expressed upon all occasions in our conduct including esteeming them which should be shown in our conduct;

2. Obedience to their lawful commands which should be expounded from the principle of love, come when they call you, go where they send you, do what they bid you, refrain from what they forbid you; and this, children should do cheerfully, and from the principle of love.

3. Submission to their rebukes, instructions and corrections; not only to good and gentle but also to the forward, out of conscience towards God. Endeavouring in everything to be the comfort of their parents and also and to make their old age easy to them, maintaining them if they require support, which Savior makes to be particularly intended in this commandment.

The above assertion was made because the destruction of the home through disrespect to parents would be the beginning of the destruction of family morality and to maintain the moral principle of the home children were obligated to honour their parents as they did to God. Misconduct and disrespect may break the heart, or shorten the lives of parents and a violation of the fifth commandment.

Though Coffman's Commentaries agrees with other scholars on the division of the Decalogue into two, a division honoured by Christ himself who marked the divisions as "Duties to God," and "Duties to Man" (Mark 12:28-31), they disagree on the question of placing them. For instance

a. The Jewish division of the Decalogue places Commandments I-V on Table I, and Commandments VI-X on Table II, thus including the duty to parents on parity with the duty to God.

b. The usual Protestant division places Commandment V on Table II among duties to men, giving the divisions as I-IV and V-X.

c. The Catholic division omits II altogether, splits $\mathrm{X}$ in two to retain the total number, and thus divides them: I, III, IV, V on Table 1, and VI, VII, VIII, IX, Xa, Xb on Table II. The insignia for chaplains in the Armed Services of the United States follows the Jewish mode, and that of Jewish chaplains is the Star of David.

Coffman asserts that Jesus Christ acknowledging the authenticity of the Decalogue affirms "God" as the Author (Matthew 15:4) and taught that duties to God must be higher than duties and obligations to people (Mark 12:28-31). He also pointed out that Jesus did not soften or abrogated any of these laws rather he expanded the prohibitions to include antecedent motives and attitudes of sin, making even the honouring of father and mother as a precondition of attaining eternal life (Matthew 19:16-20). Paul reechoing the fifth commandment in the Decalogue pointed out the need for "Children to obey their parents in the Lord: for this is right. Honour your father and mother (which is the first commandment with a promise), so that you may live long on the earth" (Ephesians 6:1-3 KJV).

Disobedience to this commandment has been widespread in all ages. Even in the times of Christ, the Pharisees in an attempt to avoid caring and supporting their parents had 
to devise a means to circumvent this law. This was called Corban. Corban was an Old Testament practice that generally supported the dedication of gifts to God. It was mostly used to refer to properties dedicated as gifts to God (Lev. 1:2-3, 2:1, Num. 5:15, 6:14). This practice was condemned by Christ in Matthew 15:3-6 because the Priests and Temple keepers circumvented the practice and misinterpreted the concept from the original meaning to suit their selfish interest. The taught that property, money or anything dedicated to the temple as "corban" belong to the temple and could not be used for any other purpose. The reason for this interpretation was to exempt the usage of those dedicated temple items for other purposes. The gift that was supposed to be kept by those who made the vows were made exclusive of the giver so that they could take full possession of their gift. Yet according to this practice, a son could avoid his responsibility to support his old and indigent parents merely by saying that his property or part of it was corban, a gift dedicated to God or the temple and deny his parents the need or assistance that they might desperately need. This pretense or hypocritical irresponsible attitude was what Jesus condemned in Matthew 15: 36, Mark 7:11.

The modern generation is no exception in abusing the moral law in Exodus 20: 12. Today, youth hardly desire the wisdom of their parents. Most youths are impatient and disrespectful to their aged parents and look at them in a disdained and amusing manner. Coffman alluded in his assert that:

The apparent gulf that separates some young people from their parents is merely a youthful fantasy, due to pass away in time, just like acne. Five things are promised to those who obey and honour their parents: "These are: (1) grace in the present life and glory in the life to come; (2) long life upon the earth; (3) grateful and pleasing children; (4) a good name; and (5) material wealth (Coffman Bible Commentary)

Theologians like Matthew Henry, Coffman believe that this commandment was made to protect the foundation of the home because the home is the basic building block of civilization. And if there must be a better world, it must begin with better homes. The home is the place where youths must learn to accept, obey and honour authority. And if this is not done children may grow up as troublemakers in society and conclude that the beginning of all law and order lies within the fifth commandment.

The honouring of father and mother is the divine order, not merely for children and young people, but all people. Those Pharisees whom Jesus condemned for their godless neglect of this commandment, were in no sense "young people," but the leaders of the Jewish nation (Matthew 15:5-6). Societies today are under attack by all the forces of evil, and the home is primarily the focus of that attack. The young should realize what they have to lose if they join with the forces dedicated to its destruction.

\section{The Efik Concept Of Ageing And Respect}

The Efik structured nuclear and extended family system assisted in regulating and inculcating habits and behavioural patterns in the life of individuals in many ways. Before the advent of colonialism and Christianity among the Efik people, most families lived in stable and homogeneous communities. The family was a key institution that shaped the individuals and society. The stress on community ties in Africa meant everything to them. A distortion of the family ties meant a distortion of society. A person is defined in terms of the group to which he or she belongs. This sense of community was gained through the family, the lineage, the clan, and the tribe. In Efik's traditional societies, the family was not simply 
made up of father, mother and children. It comprises a whole group of persons: the head of the family with his wife or wives, his children, and grandchildren, and also his brothers and sisters with their wives and children, his nephews and nieces, in a word, all the persons who descend from a common ancestor. Among the Efik people, there are no separate words for cousins or nephews or nieces; every person is either a brother or a sister. It is not how large this family is that is important, but what role they play in keeping together the family members. In it, every person had a place. The young people were treated with love and kindness; the elders were respected and consulted for their wisdom and experience and also as the custodians of traditional norms and values.

The Efik concept of family was highly influenced by the ideology and worldview that goes beyond the living members. The ancestors and all the dead members were part of the larger family. That is to say that the family never reduces in number. Those who are married into the family and the children born into it help to swell the number. The dead relatives or the "living dead" remain permanent members. It was this bond that sustained the people in virtually everything they did and believed. Welfare services were designed and provided to meet the need of everyone in the family including the aged, the widows and the orphans. The Efik communal lifestyle is adequately captured by John Mbiti's when he said: In traditional Africa, the individual does not and cannot exist alone except corporately. He owes existence to other people, including those of past generations and his contemporaries. Whatever happens to the individual is believed to happen to the whole group, and whatever happens to the whole group happens to the individual... The individual can only say: 'I am because we are, and since we are, therefore I am'. This is a cardinal point of understanding of the African view of man (Mbiti 1990 p.106).

This sense of community and humane living was a highly cherished value among the Efik people and it acts as a binding force in the life of the people (Eyo 2011). For Efik people, social life was sacred, rather than secular, and surrounded by several religious forms and symbols. Community is much more than simply a social grouping of people bound together by reasons of natural origin or deep common interests and values (Akpanika 2020). Rather it was both a society and a unity of the visible and invisible worlds; it was the world of the living and the world of the ancestors, divinities including the souls of children yet to be born to individual kin-groups. In a wider sense, Efik's traditional community incorporates the totality of the world of African experience including the physical environment, as well as all spirit beings acknowledged by a given group. This idea and structure of human society was essentially part of the Efik worldview that gave them full meaning and significance to their ultimate reality.

Today, the Efik family setting represents a major drift from the traditional community and communal setting. The western individualistic setting has weakened the community and communal Efik family structure, the primary or kinship relationship is taken over by the secondary economic relationships and this has affected the structure of the family. The effect is the rejection of the normative values for parents and the aged which places a moral obligation on every member of the family to care for one another. The desperate search for money and material things has weakened the human sympathy and empathy that Efik people were once known for. Kaunda giving a proper perspective of a tribal society like Efik represents asserts that:

The tribal society was a mutual society. It was organized to satisfy the human needs of all its members and, therefore, individualism was discouraged....the 
tribal community was accepting. It did not take account of failure in an absolute sense. The slow, the inept [aged] and incapable were accepted as a valid element in community life,... [The kinship system was based on respect for elders and reverence for ancestors] (Kaunda 1978 p. 137).

These traditional views of living and sharing in an extended family system and regarding the aged as noble, full of wisdom, custodians of traditional knowledge, norms and values to some extent regulated the respect that was accorded to parents and the aged in the family. Despite being a socially cohesive society, the disintegration of the extended family system has remarkably affected the revered status of the aged. Besides, the emphasis on youths and the transition from extended to the nuclear family system has put aged parents at a disadvantage position. The younger ones are now more independent and are making decisions that were hitherto decisions of the parents for themselves without reference to the aged parents. The effect is that aged parents are being marginalized putting them more in a position of dependency both economically and socially. Also, the rural-urban drift has led to the departure of young ones who were hitherto left at home to assist their parents and grandparents. This condition in most cases forces them to live alone with no one to assist or attend to their social, economic and psychological needs resulting in untold hardship to the aged, untimely death as a result of lack of money to cater for their basic needs of health and food.

Among the Efik people, the seniority principle is typically symbolized through distinct etiquettes regulating formal interaction between the seniors and the juniors. For instance, respect for seniority was a virtue that could not be compromised in Efik ethical structure. Respect for old age was deeply ingrained in the moral and ethical code and properly reflected in the people's greetings to their Chiefs and seniors at public and family gatherings, naming ceremony and marriages. From birth, the juniors were taught to respect, honour and obey their seniors. According to Onoyom Ukpong:

...Juniors were taught to respect their seniors in all aspects of interpersonal activity both in private and public spaces. It is a necessary condition of greeting for a junior male to use both of his hands to shake a senior male, but the latter must initiate the greeting. Unlike their male counterparts women seldom shake hands but would embrace themselves, their husbands, and close male relatives. Stealing is a taboo that attracted severe punishment and alienation to the extent that prospective marriage partners were discouraged from marrying a member of a family with a criminal history (www.efikusa.org/efik-history).

Greetings played a major role in Efik social structure and this was because of the importance attached to seniority in society. Everybody knew their limits on every occasion and needed to adhere to it for harmonious peaceful co-existence and the smooth running of the society. According to Akak:

In greetings, juniors first greeted seniors also. The belief in the exchange of greetings was very strong especially in the morning because failure to greet a senior person by whoever saw him or her first at the early hours would mean bad luck to him or her for the whole day. But seniors shared things to juniors, each of whom had to choose in order of the age from eldest first to the least or the last (Akak 1982 p. 276). 
There were some polite ways of greetings or salutations for every occasion or event for each group. These various methods of greetings regulated the behaviour of each person depending on the occasion and the class or status of the person to be greeted. The way juniors greet their seniors, parents, elders and peer groups differs both in language and gesture. For instance, men bow to their seniors while women bend their knees. For people of the same age grade, men shake hands with their colleagues while women embrace themselves. For secret cults members like Ekpe, Obon, Akata, their coded greetings are only known to their members. In a mixed social gathering, younger persons are not permitted to speak or share a drink unless duly recognized and permitted to do so. Ukpong confirms this when he said: If a junior person passes or comes by an elder and fails to greet him, the elder may turn around to greet his junior in an attempt to draw his attention. The junior person would not answer the greeting but would rather greet the elder, pretending not to have heard or forgot to greet. In that case, the junior person

would be ashamed and embarrassed. In [Efik] culture, juniors remove their caps or hat and bow their head to greet their elders but not expected to kneel or kow-tow before an elder as in the case of Yoruba or Hausa (www.efikusa.org/efik-history).

While it was a duty for juniors to greet their seniors, the seniors had the duty of pronouncing blessings upon the junior ones by saying. "Eyen mi, itong uwem osong fi ooo" meaning may you live long. It is customary that the prayer of an old man to the younger ones always included blessings. In public gathering, the family head will traditionally salute his people as follows: "Oyea, oyea bab Ufok, Oyea, oyea bab Uforo, Oyea, oyea bab ayan uwem, Oyea, oyea bab ima, Oyea, oyea bab nsong idem" and the people in response will say "itong uwem osong amasi nyin ooo". Meaning long live our king and may you live long to see your children or may you live to reap and eat the fruits of your labour.

In Efik traditional society, old men were not only respected on the account of their long years but also the account of their wisdom. Therefore, respect was almost mandatory on the younger ones and any kind of insult or disrespect to the elders attracted some punishment. Violations of such little etiquette could lead to a very serious case that could make the offender appear before the Council of Elders with some stated fine. This method prevented abuse and secured honour for the elders. This ethical structure guided the socio-political and religious orientation of Efik people and helped in maintaining the social equilibrium for centuries.

This was achieved through the house system, which regulated and naturally apportioned roles to every person within the system. Family leadership was the prerogative of the eldest member of the family unless he the eldest was incapacitated by sickness and in that case, he must decline his headship before the next in age is accepted.

For the Efik, succession to headship whether at family, village or clan level, was mainly patrilineal even though matrilineal factors were considered. The eldest living son comes first in the line of succession to inheritance and the family headship before other sons will follow in the order of seniority by age. Succession is not heredity as from father to son in the case of the father's demise, nor is it the choice of the deceased family to immediately produce the next successor to the throne, but the choice of a successor rests with the members of Etuboms Council, who determines the next family that qualifies by rotation among the ruling families, after the burial of the incumbent. Until recently, one of the criteria for the 
selection of Etinyin, Etubom or Obong was age. Almost in all cases, the oldest man in the ruling family was chosen as the family, village, clan or as the Obong of Calabar.

In Efik land, it is not customary to change Etinyin, Etubom or the Obong once he is sworn in except by death. Indeed, it is cardinal and widely accepted customary law that no Chief must be changed until he dies except in cases of gross misconduct tan-amounting to disloyalty or disobedience to the higher authority which they swore allegiance to. Their forefathers seemed to have been aware of the fact that there could be intrigues and manoeuvres from ambitious people to remove a ruling chief and get themselves installed. In a case of a chief not ruling well, it is not in Efik custom to remove him. His authority may be greatly undermined and his government noted for weakness and inefficiency, but he cannot be removed or replaced until he dies. Like in every aspect of tradition, the government has come to interfere with and changed the concept of the irremovability of the ruler.

Again, the traditional disposition of aging and longevity among the Efik people were rooted and well expressed in many of their religious and philosophical sayings, portrayed in ballads and proverbs that form their everyday life. Most Efik ballads are philosophical and pregnant with moral insights. It takes wisdom and intelligence to gain an understanding of the meaning and interpretation of it. Through proverbs and riddles, youths were challenged to seek wisdom for everyday living as well as to examine the qualities and virtues that constituted an ideal lifestyle. For instance, among the Efik, it is generally believed that "etim adie ebighi uwem", meaning that, "carefulness, wisdom and understanding is the wheel of long life". The ethical implication is that, moral uprightness and good character enhances long life; that a man is not established by wickedness but by a righteous character. For Efik people, long life is attributed to uprightness and good character. In an oral interview with Etubom Nyong Inyang, a Traditional Ruler, comparing traditional Efik values to the aged or elderly people then and now, said what is obtainable today is a total deviation of what use to be. In those good old days, uprightness and good character was a virtue that was highly cherished and sought after. According to him, character, integrity and uprightness were preferred to wealth, money and fame. A man was defined not necessarily by his wealth or fame but by his character and integrity. A good family name was, therefore, better than silver and gold. For the Efik people, a poor man with the character was respected and honoured in the society than a rich and wealthy man whose sources of wealth was uncertain. This kind of check and balances in the traditional Efik society prevented inappropriate behaviour and encouraged character modelling among the youths.

Another proverb that has a profound philosophical meaning to the Efik people is "Owo edi esio edi usiong" meaning "the young shall grow old". This proverb implies that nothing on earth is permanent. The strength, vigour and vitality of the youths today will certainly diminish with time. Despising old people because of their frailty and weakness was not encouraged. The aged today was once young. Everything is subject to change. No matter how handsome and beautiful one maybe today, over time will be old. The aptness of the old saying by an anonymous author reflects the attitude of Efik people that there is no permanent condition:

Never look for a good face, it will turn old one day. Never look for good skin, it will wrinkle one day. Never look for a perfect body, it will change one day. Never look for nice hair, it will turn white one day. Instead, look for a loyal heart that will love every day.

In an interview with HRH Etubom Efiom Okon on the disposition of the aged among Efik people, he gave this proverb to illustrate his point "Esio ebeghi uwem etem unam enang, 
awara dikpa etem ikong ubong". Meaning death at full old age is a celebration but untimely death is a pain to the people. According to him, among the Efik people, dying young is detestable, painful and regrettable. Anyone that lives his full age is celebrated with feasting and fan-fare but when one dies young or prematurely, it is a shame and does not call for celebration.

Nsat okokog ukot ekedi ekpin. The dry palm front was once fresh. Asua eka nkpong imagha mbo.Itong odu uwem Okoho nkwa, Uwem edi obong, itong edi uko "Ebe iso idim, enye ofiok usung" Uwen etiente urua, ayam ama oyong, Uwen edi obong

Most of these proverbs and adages were remarkable because it acted as a deterrent to unethical practices among the Efik people. Life was to be respected at all level since it is a gift from God. Behaviours were largely regulated by some of these customs rather than formal laws. The observation of William G. Sumner is quite fitting into the Efik traditional system when he said:

where mores, as well as informal norms, exercise a stronghold upon behaviour, there is little need for formal law. Law we might say is part of the tradition, it is not modified or rationalized; not enacted or dictated, but emerges from the culminative experience of the society; it is incorporated in the customs known and accepted by members (Summer 1965 p. 47-48).

For the Efik people, there is a simple division of labour in the traditional structure that defines the roles and the function of each group within the society. Sex roles and age roles are most important because of the social, economic and religious functions of males and females (Merab 2015; Eyo 2020). By one's sex and age, a person's behaviour, status and function are determined.

\section{Common Areas Of Abuses And Disrespect Among Efik People}

Though issues of abuse differ from culture to culture, among the Efik people witchcraft accusation constitute a major act of abuse among the elderly. This is because once you are accused of witchcraft, you are avoided, neglected and feared; such people are hated and dreaded. Their companies are carefully avoided for fear of being initiated or becoming their victim; people avoid eating, sharing, greeting or attending to them. This has become a common decimal for most elderly people in Efik society.

Witchcraft is a common phenomenon that is usually associated with the aged or the elderly. Witches are believed to have some supernatural powers that enable them to cause misfortunes on whosoever they desire to harm. They are capable of getting access to their victims no matter where they live, distance notwithstanding. For them, the easiest way to detect the reality of witchcraft is through frequent misfortunes in the family. Most sicknesses, accidents, diseases, pre-mature death, unemployment, barrenness and retrogression in the family are always attributed to the diabolical acts of witches and once one is suspected of this evil power, nobody cares anymore. Their companies are carefully avoided for fear of being initiated or becoming their victim; people avoid eating, sharing, greeting or attending to them.

Once a person is suspected or accused of witchcraft publicly, you can only declare your innocence or otherwise by undertaking the Ordeal of Esere beans. Esere beans are a species of beans among the Efik people possessing a powerful narcotic poison used in detecting persons with witchcraft. Naturally, Esere beans are poisonous and deadly but when well-cooked it loses its poisonous nature and becomes non-poisonous. It is believed that 
those who chew and swallow esere beans and escape death are innocent of witchcraft accusations while those who die are guilty. Many elderly persons have been accused, abused and violently sent to their early grave through this ordeal.

By the researcher's observation and throughout a growing period among the Efik people, the researcher has never witnessed anyone economically self-sufficient being accused of witchcraft. The least they could be accused of, is that they are wicked, stingy or parsimonious. It is often the poor, the downtrodden and those financially handicapped that are usually victims of witchcraft accusations. The rich are hardly accused.

Other forms of abuse and accusation may include, physical abuse, derogatory namecalling, threats and yelling on elderly persons at the slightest misbehaviour. Locking them in a room and refusing them access to the sitting room. Negligence such as late feeding even when they are hungry. Refusal to refresh them as of when due. Financial exploitation, such as controlling their money or sometimes stealing their money. All these constitute abuses against the elderly.

\section{Factors Responsible For Disrespect And Abuse Among Elderly People In Efik Society}

\section{a. The Disintegration of the traditional nuclear family structure:}

The western individualistic setting has weakened the community and communal Efik family structure, the primary or kinship relationship is taken over by the secondary economic relationships and this has affected the structure of the family. The effect is the rejection of the normative values for parents and the aged which placed a moral obligation on every member of the family to care for one another. The desperate search for money and material things has weakened the human sympathy and empathy that Efik people were once known for. The tribal society was a mutual society. It was organized to satisfy the human needs of all its members and, therefore, individualism was discouraged. The tribal community was accepting the community. The slow, the inept [aged] and incapable were accepted as a valid element in community life, the kinship system was based on respect for elders and reverence for ancestors.

These traditional views of living and sharing in an extended family system and that regulated the respect that was accorded to parents and the aged in the family is no more. The disintegration of the extended family system has remarkably affected the revered status of the aged. Besides, the dominance of individualistic values to communal values, selfish interest to the common good has gradually replaced the hospitality and caring spirit of Efik people to their aged parents. This socio-religious change and cultural shift from the traditional communal views to the modern individualistic western lifestyle has raised some social, ethical and religious questions especially with regards to the care given to the aged and the increasing abuse meted to the elderly (Enor et al 2019).

\section{b. The Breakdown of ethical norms and values due to globalization and urbanization}

According to Perrucci and Knudsen (1983), norms are expectations that define what is acceptable or required in a social situation, they specify how people should and should not behave in various social institutions. On the other hand, values are standards set by the society which serve as guides to what is right and proper for people in that society. The advent of colonialism had a telling effect on Efik indigenous culture. It distorted degraded 
and disoriented Efik people from their indigenous cultural values and practices. The spread of Western cultural values through the process of globalization has weakened the traditional value of respect that Efik youths had for their elders and the aged. The well-structured ways of Efik greetings that distinguished the youths from their seniors is now replaced with the Western cultural method where a small child will simply say "Hi" to his parents and his seniors. The advocacy for gender equality has further weakened the traditional institutions that regulated those norms. From the Children to the taxi driver who shouts and yells and abuse the elderly and the aged both at home and on the street to the Policeman who does not bother to protect or assist them cross a busy road, to the government who persistently ignore the plight and cry of the elderly and the aged over their pension, to the countless families who dump their elderly parents in the villages uncared for with visits occurring once or twice a year. The social mechanism that held Efik value systems and enabled the smooth functioning of Efik society has been weakened and the centre can no longer hold. Obedience and loyalty are now conditional. Obedience to parents is no longer sacrosanct, a son can take his father and mother to court where they disagree, Children could marry without the consent of their parents, Children could buy and build their house without the knowledge of their parents. This is the trend that makes it difficult for children to still be loyal as demanded in Exodus 20:12.

\section{c. Poverty and Over Dependency of parents on their Children}

Scholars agree that poverty is a serious challenge among older people, especially in developing countries. The majority of the aged in contemporary Efik society is poor. The poor are those who barely have enough to survive. They struggle to obtain the necessities of life and this reduces them to the level of the animal. Poverty has been cited as the worst problem of many old people, their chief source of unhappiness and worry. They become an easy target of abuse and insult by their own children or caregivers because of their total dependency on others. They become an easy target of abuse because of their poor financial status and dependency (Yte et al., Yte 2016; Yte 2017; Eyo 2018). Besides, poverty is not restricted to those who fall below a certain level of subsistence but also include those who suffer from diverse circumstances such as the sick, the physically handicapped, the orphans and the widows. Poverty in its entire ramification is demeaning, isolates people from their family and friends; puts people at the mercy of others, encourages insult, abuse and disrespect. This is the condition of some of the aged people in our society today. Generally, in developing countries, there is no social security and this is further complicated by the fact that there are no youths to work on them in their farms or provide income for them. Most of the youths are located far away from their aged parents. In the past, this was not the case. Usually the aged stayed at home while the youths work either as pastoralists or farmers, as the case might be, to sustain the entire family, including the aged. It is quite sad that some people who participated in the contributory pension scheme during their active service years with the hope of a better retirement life are regrettably unhappy with the scheme. This is because of the endemic nature of corruption associated with the scheme.

\section{d. Poor Health Condition of most Elderly Persons:}

Old age brings with it unique ailments. Certain illnesses are unique to the elderly and have become more pronounced as the aging process continues. It is usually accompanied by the physical manifestation of signs like loss of hairs, grey hair, wrinkles on the skin, 
weakening of sight, loss of memory (dementia), weak bones and other symptoms. This deteriorative biological process is what brings health challenges to the elderly. The human body is interrelated and functions in a balance; but as one age, imbalances begin to take place in their body cells giving rise to various physical and emotional changes such as high blood pressure, diabetes, heart disease, renal disease, rectal prolapsed, prostate gland enlargement which is common among men, bone fracture, cancer and other debilitating diseases that are common to the elderly.

\section{CONCLUSION}

This paper examined the biblical injunction of Exodus 20:12 to honour one's father and mother and its implication among the Efik People of South-South, Nigeria. It is very clear from the study that God gave the children of Israel this moral law to guide their relationship with the elderly and protect them against abuse and neglect. Similarly, among the Efik people, they had some moral laws that protected the elderly from possible abuse. These obligatory respect for the elderly acted as a panacea for family stability both in the patriarchal period and Efik traditional setting. Violations of these moral laws attracted some punishment basically because of the communal nature of traditional societies. Today, the setting is different. The capitalistic and individualistic nature of today's society makes it difficult to actualize this mandate. The dependency status of elderly people, low resources and restricted access to resources renders them vulnerable for abuse and insult. However, following the recommendations below will help reduce the level of abuse and insult meted on the elderly people in our contemporary society.

\section{REFERENCES}

Akak, E. O. (1982). Efik of Old Calabar: Culture and Superstitions. Vol. iii. Calabar: Akak and Sons.

Akpan, E. A. (2013). Preparing for a Happy Retirement. Calabar: PENA Printers.

Akpanika, E. N. (2020). Religious and Cultural Conflicts: A Critical Appraisal of the

Scottish Mission Activities Among the Efik People of Old Calabar. In Handbook of Research on the Impact of Culture in Conflict Prevention and Peacebuilding (pp. 249-266). IGI Global.

Atchley, R. C. (1983). Ageing: Continuity and Change. Belmont: Wadsworth.

Cavanaugh, J., Fredda Blanchard-Fields, Joan E. Norris, (2002). Adult Development and Ageing (4th Ed.). Wadsworth: Thomson Learning.

Enor, F. N., Edet, A. S., \& Etim, A. E. (2019). Archaeology, History and the Monoliths Heritage: Nta Akwansisi in Perspective. Academic Journal of Interdisciplinary Studies, 8(3), 248-248.

Eyo, U. E. (2011). An interpretation of" And the Word became flesh and dwelt among us"(John 1: 14) to the Efik people. Institut oecuménique.

Eyo, U. E. (2018). Divorce: Causes and Effects on Children. Asian Journal of Humanities and Social Studies, 6(5).

Eyo, U. E. (2020). Creation accounts in Gen. 1 \& 2: A Feminist Interpretation. International Journal of Humanities and Innovation (IJHI), 3(1), 29-33.

Fisher, D. H. (1978). Growing Old in America. New York: Oxford University Press.

Hooyman, N. R., H. Asuman Kiyak (1996). Social Gerontology: A Multidisciplinary. Boston: Allyn and Bacon. 
Jurnal Sosialisasi

Jurnal Hasil Pemikiran, Penelitian, dan Pengembangan

Keilmuan Sosiologi Pendidikgan

Vol 7, Nomor 1, Maret 2020

Ituen, M. (2010). The Secrets of Longevity. Uyo: Deosa.

Iwe, N.S. S. (1986). The Early Christian Beginnings. London: Merline Books Ltd.

Kaunda, K. (1978). "Humanism and Community in Africa." Shorter, Aylward. In African Christian Spirituality. London: Geoffrey Chapman.

Kosberg, J. I. (2007). Abuse of Older Men. Binghamton: The Haworth Maltreatment and Truama Press.

Loether, H. J. (1967). Problems of Ageing: Sociological and Social Psychological Perspectives. Belmont: Dickenson.

Mbiti, J. S. (1990). African Religion and Philosophy. London: Heinemann, 1990.

Mboto, W. A. (2002). Introduction to Sociology of the Aged. Calabar: Clearlines Publications.

Merab, Y. E. (2015). Changing Trends in Dreamboat Children's Theatre, Calabar, Nigeria. Indian Journal of Applied Research 5 (8), 582-586

Muddiare, P. E. U. (2013). "Abuse of the Aged in Nigeria: Elders Also Cry" American International Journal of Contemporary Research. 3. (9).

Ndukwe, O. (2011). Celebration of Life, Religion, Mission and Victims of Society: A Christian Theological Engagement. Enugu: Precious Grace Publication.

Novak, M. (2012). Issues in Ageing. Boston: Pearson Education.

Obioha, R. (2008). Our Pact of Poverty. Lagos: Daily Sun Newspaper.

Okon, E. E. (1998). "Religion and Communal Solidarity Among the Ibibio of Nigeria." Unpublished PhD Dissertation. Calabar: University of Calabar, November.

Oluwabamide, A. J. (2007). The Aged in African Society. Ikorodu: Nade.

Onoyom, U. (n. d.). A Brief History of the Efik. www.efikusa.org/efik-history, Retrieved May 15, 2020.

Perrucci, R. and D. D. Knudsen (1983). Sociology. St Paul, Min: West Publishing Co.

Pritchard, J. (1992). The Abuse of Elderly People: A Hand-Book for Professionals. London: Jessica Kingsley Publishers Ltd.

Summer, W. G., Thomas E. Lasswell, John H.Vurma and Sidney H. Aronson (1965). Folkways and Mores in Life and Society: Introductory Readings in Sociology. Chicago: Foresman and Company.

Townsend, P. (1979). Poverty in the United Kingdom, London: Allen Lane and Penguin Books.

Yta, E. M. (2016). Changing Meanings in Patterns of Efik Women Hair Styles. A Journal of Theatre \& Media Studies 1 (2), 192-207

Yta, E. M. (2017). Using identification in entertainment-education drama serials to promote women's rights in Cross River and Akwa Ibom States. Lwati: A Journal of Contemporary Research, 14(4), 301-320.

Yta, E. M., \& Umukoro, G. M. DESIGNS IN CARNIVAL CALABAR._DUÑ_DE: CALABAR JOURNAL OF THE HUMANITIES, 413.

Yta, E. M., Ekpe, I. A., Offiong, R. A., \& Umoh, N. E. (2015). Assessment of income poverty among farmers in Akwa Ibom state, Nigeria. Journal of Emerging Trends in Economics and Management Sciences, 6(8), 345-349. 